\title{
PENGARUH DANA OTONOMI KHUSUS TERHADAP INDEKS PEMBANGUNAN MANUSIA KABUPATEN/KOTA DI PROVINSI ACEH
}

\author{
Muhammad Hijrah Saputra \\ Pusat Informasi dan Kajian Ekonomi (Pike) Aceh \\ Jln. T. Iskandar No. 174A, Lamglumpang-Ulee Kareng, Banda Aceh \\ Email:jackden@rocketmail.com \\ Cut Zakia Rizki \\ Jurusan Ekonomi Pembangunan \\ Fakultas Ekonomi Universitas Syiah Kuala \\ Kampus Universitas Syiah Kuala, Darussalam, Banda Aceh \\ Email: zakia rizki@yahoo.com; zakia rizki@fe.unsyiah.ac.id
}

\begin{abstract}
This study aimed to determine the effect of the Special Autonomy Fund Against Human Development Index in Aceh, to achieve these objectives, this study uses the Human Development Index (HDI) as the dependent variable and the Special Autonomy Fund (Autonomy) as independent variables. The data analyzed in this study are secondary data from the reports on the realization of the Government's budget 23 districts / municipalities in the province of Aceh which was obtained through a survey BAPPEDA Aceh and the Central Statistics Agency (BPS) of Aceh. The data used are panel data which is a combination of Time Series and Cross Section. Data time series used is the 23 districts / cities in the period 2009 2012. The method used in this study is one of three in a panel data analysis techniques that pool (common) effect model, fixed effect model and random effect model. Based on data processing studies concluded that the SAF has a positive and significant effect on the Human Development Index, which the SAF increase in tandem with the increase in the Human Development Index. So it can be concluded that the increase in SAF positive effect on the Human Development Index in 23 districts / municipalities in the Aceh Province.
\end{abstract}

Keywords: Human Development Index, Special Autonomy Fund, Panel Data

QE Journal | Vol.03 - No.04 December 2014 - 246 


\section{PENDAHULUAN}

A egara Republik Indonesia merupakan negara kepulauan yang terdiri dari suku-suku dan budaya yang beranekaragam, terdapat banyak perbedaan di dalamnya, khususnya dalam hal proses aktivitas kehidupan, namun untuk menunjung tinggi nilai-nilai dari perbedaan itu, dibutuhkan sebuah konsep hukum kenegaraan yang mendukung nilai dari perbedaan tersebut yang sesuai dengan prinsipprinsip karakter di suatu daerah.

Konsep hukum kenegaraan yang di atur didalam Undang-undang maupun keputusan presiden diantaranya membahas tentang penerapan Otonomi Daerah (Otoda), hal ini didukung oleh negara yang mengakui serta menghormati satuan pemerintahan daerah yang bersifat khusus adalah daerah yang diberikan Otononi Khusus (Otsus) untuk menjalankan suatu pemerintahan daerah yang bersifat mandiri sesuai dengan amanah Pasal 18B UUD 1945.

Berdasarkan ketetapan MPR RI Nomor XV/MPR/1998, Otonomi adalah suatu pemberian hak dan kewenangan kepada daerah dalam penyelenggaraan pemerintahan. Kewenangan tersebut diberikan secara profesional yang diwujudkan dengan pengaturan, pembagian, dan pemanfaatan sumber daya nasional yang berkeadilan, serta perimbangan keuangan pusat dan daerah.

Dalam rangka menciptakan pemerintahan yang aktif, responsif, dan aspiratif untuk memenuhi kebutuhan masyarakatnya, pemerintah pusat menerapkan hak Otsus di Aceh yang diawali pada tahun 2001 yang turut dikonsepkan dengan konsep otonomi yang diwujudkan melalui UU No. 18 Tahun 2001 tentang Otonomi Khusus bagi Provinsi Aceh. Diberikannya Otsus kepada Provinsi Aceh karena kekhasan karakter yang dimiliki masyarakat aceh, selain itu juga sebagai wujud penghargaan negara terhadap dedikasi dan perjuangan yang luar biasa dari Aceh selama perang kemerdekaan, dan diharapkan pemberian Otsus ini juga dapat meminimalisir berbagai permasalahan yang ada di internal Aceh.

Penerimaan dana Otsus ini dimulai pada tahun 2008 dimana pada tahap pertama Aceh menerima dana sebesar 3,59 triliun rupiah, jika dijumlahkan total penerimaan dana Otsus selama enam tahun terakhir diperkirakan sebesar 27,1 triliun rupiah (Bappeda Aceh, 2013). Kemampuan keuangan 
ini menjadi pertanyaan besar bagi pemerintahan Aceh apakah Aceh mampu mengalokasikan dana tersebut untuk meningkatkan kesejahteraan masyarakatnya; mengentaskan kemisikinan, meningkatkan pendidikan, mengurangi pengangguran, kesehatan yang baik, dan dampak-dampak lain yang mengarah kepada suatu indikator kesejahteraan masyarakat melalui Indeks Pembangunan Manusia (IPM).

Dalam hal Indeks Pembangunan Manusia, Aceh mengalami peningkatan, namun selisih jarak antara IPM Aceh dengan IPM Nasional dari tahun 2008 sampai dengan tahun 2010 semakin membesar, artinya IPM Nasional peningkatannya jauh lebih tinggi daripada IPM Aceh. Bila pada tahun 2008 selisih IPM Nasional dengan IPM Aceh adalah 0,41 poin, maka pada tahun 2010 selisihnya menjadi 0,57 poin. Hal ini mengindikasikan bahwa laju perkembangan IPM Nasional lebih cepat dibandingkan laju perkembangan IPM Aceh dan trend positif perkembangan IPM Nasional tidak sepenuhnya diikuti oleh perkembangan IPM Aceh (Badan Pusat Statistik, 2010).

Penelitian ini bertujuan untuk mengetahui bagaimana dan seberapa besar pengaruh Dana Otonomi Khusus terhadap Indeks Pembangunan Manusia di Provinsi Aceh selama periode tahun 2009 sampai dengan tahun 2012.

Penerapan Otonomi tidak akan berjalan dengan semestinya tanpa didukung dengan adanya desentralisasi. Menurut beberapa literatur teori desentralisasi, kebijakan desentralisasi di beberapa negara sedang berkembang termasuk Indonesia telah menggunakan tiga tipe teori desentralisasi, yaitu: desentralisasi politik, desentralisasi administratif, dan desentralisasi fiskal (Litvack dan Seddon, 1999 dan Shah, 1998). Penerapan desentralisasi ini memberikan peluang bagi daerah untuk lebih mandiri dalam bidang politik, administratif, dan fiskal.

Jaya (2010 : 3) menyatakan bahwa kebijakan desentralisasi dan otonomi daerah tidak hanya telah mengubah suatu aturan main yang sangat drastis (big bang changes), namun juga telah mengubah organisasi, perilaku pelaku dan sumber daya manusia. Hal ini menjadi nilai tambah bagi daerah untuk meningkatkan aspek keorganisasian dan sumber daya manusia yang mandiri.

Menurut kajian dari Desentralization Support Facility (DSF) menjelaskan bahwa perkembangan dana otsus di Aceh selama periode tahun 2008 
samoai dengan tahun 2010, pada bidang infrastruktur selalu mendapat alokasi tertinggi dalam pemanfaatan dana otonomi khusus. Alokasi untuk bidang infrastruktur pekerjaan umum pada tahun 2010 mencapai Rp. 1,4 triliun atau merupakan 37 persen dari seluruh alokasi otsus, diikuti oleh bidang pengentasan kemiskinan dan pemberdayaan ekonomi Rp. 1,02 triliun (27 persen), bidang pendidikan Rp. 672 miliar (18 persen), kesehatan Rp. 558 miliar (14 persen), keistimewaan Aceh Rp. 159 miliar (4 persen), dan Sosial Rp. 18 miliar (0,6 persen). Dapat disimpulkan bahwa alokasi penerimaan otsus terbesar pada sektor infrastruktur dan terendah pada sektor pendidikan, sosial, dan kesehatan.

Menurut United Nation Development Programme (UNDP), " Indeks Pembangunan Manusia didefinisikan sebagai proses perluasan pilihan bagi penduduk (a process of enlarging the choice of people)". IPM mengukur pencapaian hasil pembangunan dari suatu daerah/wilayah dalam tiga dimensi dasar pembangunan yaitu: lamanya hidup, pengetahuan/tingkat pendidikan dan standard hidup layak. Ketiga dimensi tersebut memiliki pengertian sangat luas karena terkait banyak faktor. Untuk mengukur dimensi kesehatan, digunakan angka umur harapan hidup. Selanjutnya untuk mengukur dimensi pengetahuan digunakan gabungan indikator angka melek huruf dan rata-rata lama sekolah. Adapun untuk mengukur dimensi hidup layak digunakan indikator kemampuan daya beli. Dimensi dasar dari Indeks Pembangunan Manusia diantaranya: (1) Angka Harapan Hidup, adalah rata-rata perkiraan banyak tahun yang dapat ditempuh oleh seseorang selama hidup. Ada dua jenis data yang digunakan dalam penghitungan angka harapan hidup yaitu anak lahir hidup dan anak masih hidup.(2) Tingkat Pendidikan, untuk mengukur dimensi pengetahuan penduduk digunakan dua indikator, yaitu rata-rata lama sekolah dan angka melek huruf. Rata-rata lama sekolah menggambarkan jumlah tahun yang digunakan oleh penduduk usia 15 tahun ke atas dalam menjalani pendidikan formal. Sedangkan angka melek huruf adalah perse ntase penduduk usia 15 tahun ke atas yang dapat membaca dan menulis. (3) Standar Hidup Layak, dalam cakupan lebih luas standar hidup layak menggambarkan tingkat kesejahteraan yang dinikmati oleh penduduk sebagai dampak semakin membaiknya ekonomi. 


\section{METODE PENELITIAN}

Penelitian ini membatasi kajian pada Dana Otonomi Khusus 23 kabupaten/kota sebagai variabel bebas (independen variabel) untuk data tahun 2009-2012 terhadap Indeks Pembangunan Manusia sebagai variabel terikat (dependen variabel), dan data yang dianalisis dalam penelitian ini adalah data sekunder yang bersumber dari laporan realisasi anggaran Pemerintah 23 Kabupaten/Kota Provinsi Aceh yang diperoleh melalui Bappeda Aceh dan hasil survey Badan Pusat Statistik (BPS) Aceh. Jenis data yang digunakan adalah data panel yang merupakan gabungan dari Time Series dan Cross Section. Data time Series yang digunakan adalah data 23 kabupaten/kota pada periode tahun 2009 - 2012.

Model analisis untuk melihat pengaruh antara Otonomi Khusus, terhadap Indeks Pembangunan Manusia, di 23 Kabupaten/Kota Provinsi Aceh menggunakan model regresi linier sederhana. Metode yang digunakan dalam penelitian ini adalah satu dari tiga teknik analisis dalam data panel yaitu pool (common) effect model, fixed effect model dan random effect model.

Model dalam penelitian ini adalah sebagai berikut:

$I P M_{i t}=\beta_{1}+\beta_{2} D O_{i t}+\varepsilon_{i t}$

Dimana IPMitadalah Indeks Pembangunan Manusia, DO adalah Dana Otonomi Khusus, i adalah Kabupaten/Kota Provinsi, t adalah waktu (tahun 2009-2012), $\beta_{1}$ adalah Konstanta, $\beta_{2}$ adalah koefisien regresi dan $\varepsilon_{i t}$ adalah error term.

Untuk memilih teknik analisa yang paling tepat antara pool (common) effect model, fixed effect model dan random effect model, maka diperlukan beberapa pengujian, yaitu Uji F, Uji Hausman dan Uji Langrange Multiplier.

\section{HASIL DAN PEMBAHASAN}

\section{Perkembangan Dana Otonomi Khusus}

Dana otonomi khusus adalah dana yang bersumber dari Pusat sebagai dana transfer ke daerah, sebagai wujud dari desentralisasi fiskal untuk kemandirian suatu daerah otonomi. 


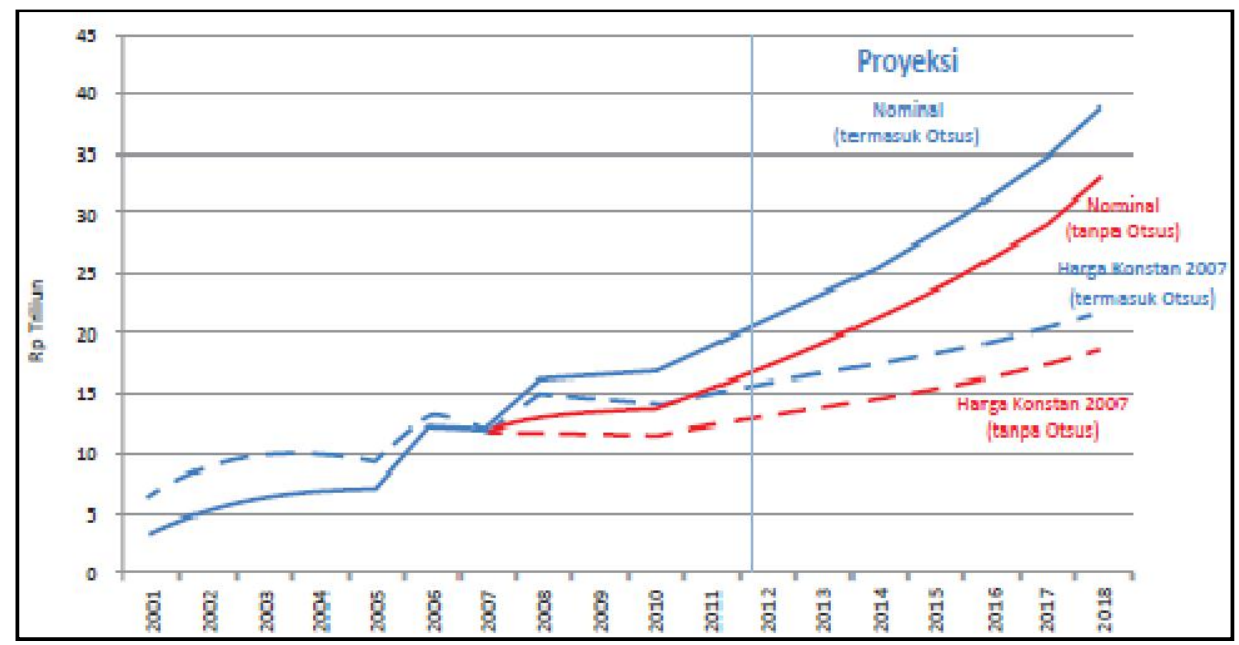

Sumber : PECAPP, diolah dari data pemerintah Aceh.2013

Gambar 1. Proyeksi Penerimaan Dana Otsus

Berdasarkan Gambar diatas penerimaan dana otsus secara keseluruhan dalam kurun waktu tersebut Aceh telah menerima alokasi dana Otsus sebesar Rp 21,15 triliun dengan rata-rata peningkatan penerimaan setiap tahun sebesar 11,42 persen. Selama 20 tahun jangka waktu berlakunya, Aceh diperkirakan akan menerima sebesar Rp 100 triliun dari dana Otsus.

Secara keseluruhan, infrastruktur memiliki alokasi tertinggi dibandingkan dengan bidang lainnya. Secara riil, pada tahun 2012, tercatat Rp. 1,40 triliun alokasi untuk infratruktur, meningkat 11,3 persen dari tahun 2010. Ratarata setiap tahun bidang ini memperoleh alokasi sebesar 39 persen, dimana alokasi terbesar diperoleh pada tahun 2008 yang mencapai 53 persen pada saat dana Otsus mulai dikucurkan. Sementara itu, dalam kurun waktu tersebut, bidang sosial dan keistimewaan rata-rata memperoleh alokasi terendah. Bidang ini rata-rata setiap tahunnya selama lima tahun terakhir hanya mendapatkan alokasi sebesar empat persen.

Secara rata-rata pada tahun 2012, setiap kabupaten /kota di Aceh menerima Rp. 117,67 milliar dari dana Otsus, meningkat sebesar 17,2 persen dibandingkan tahun sebelumnya. Dana Otsus juga merupakan salah satu sumber penerimaan terbesar bagi pemerintah kabupaten/kota di masa mendatang, tercatat sebesar 24 persen dari keseluruhan sumber penerimaan. 




Sumber : PECAPP, diolah dari data pemerintah Aceh.2013

Gambar 2. Alokasi Dana Otsus Per Bidang Tahun 2008-2012

\section{Perkembangan Indeks Pembangunan Manusia}

Perkembangan Indeks Pembangunan Manusia di Aceh Mengalami peningkatan pada setiap tahunnya.

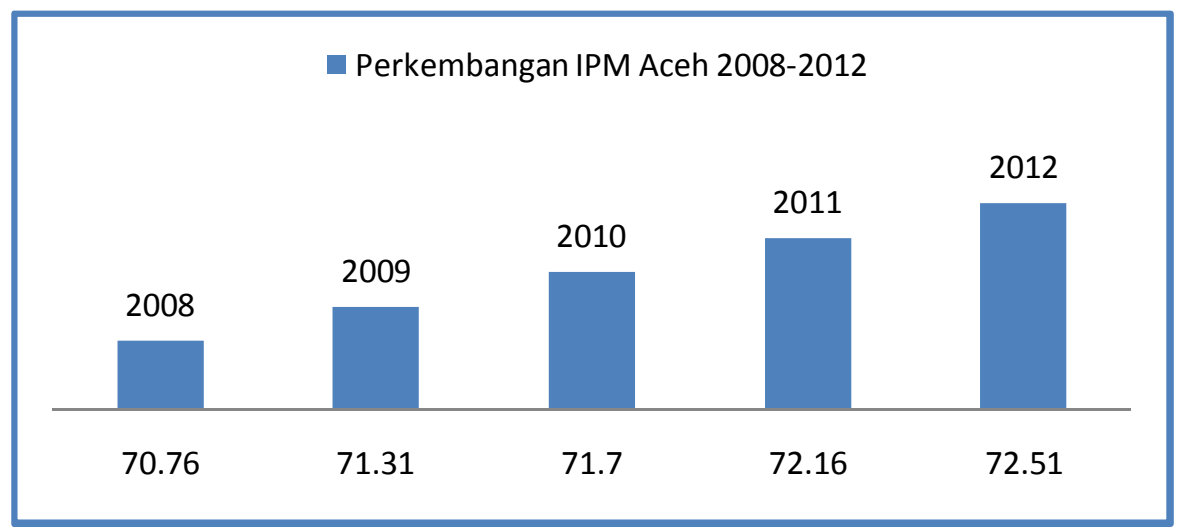

Sumber : Badan Pusat Statistik Aceh 2013 (diolah)

Gambar 3. Perkembangan Indeks Pembangunan Manusia di Aceh

Dari Gambar 3 dapat dijelaskan bahwa perkembangan Indeks Pembangunan Manusia terus meningkat pada setiap tahunnya. Hal ini disebabkan oleh beberapa faktor, baik itu tingkat penerimaan daerah yang terus meningkat maupun tingkat implementasi dari kebijakan pemerintah 
daerah dalam hal Indeks Pembangunan Manusia, sehingga berdampak kepada peningkatan pembangunan manusia di Aceh.

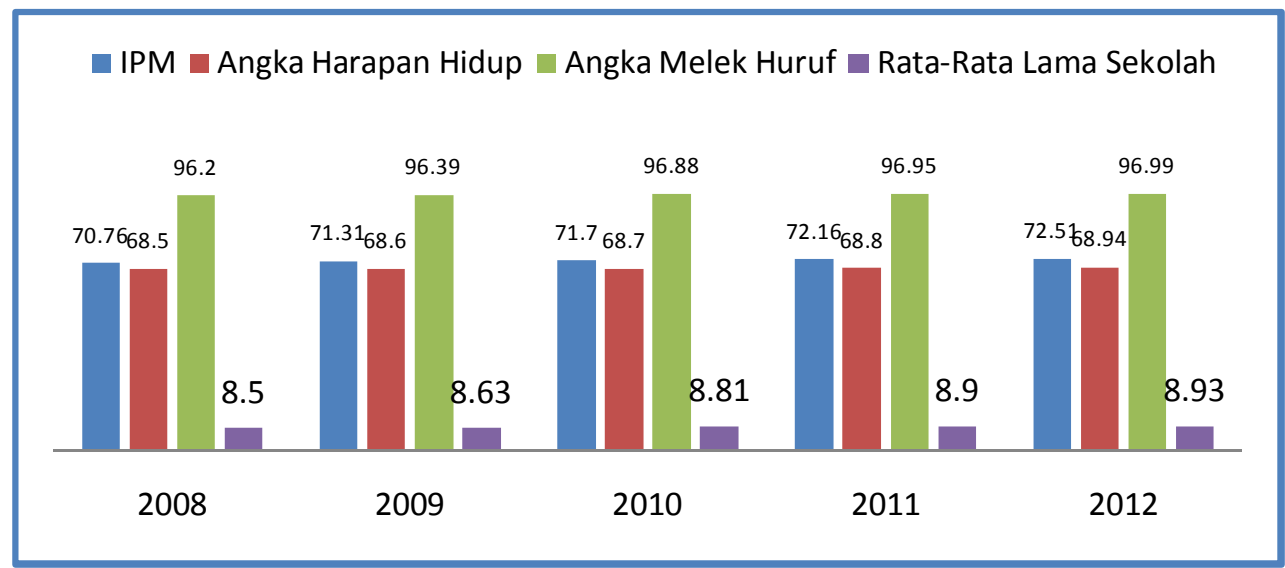

Sumber : Badan Pusat Statistik Aceh 2013 (diolah)

Gambar 4. Perkembangan IPM Aceh Menurut Komponen (2008-2012)

Pada Gambar 4 dijelaskan bahwa Indeks Pembangunan Manusia menurut komponen pada tahun 2008 sampai dengan 2012 mengalami peningkatan pada setiap komponen nya. Dimana peningkatan pada komponen Angka Harapan Hidup pada tahun 2008 sebesar 68.5 persen terus mengalami peningkatan sampai tahun 2012 yang nilai nya sebesar 68.94 persen. Pada komponen Angka Melek Huruf juga mengalami peningkatan yang signifikan, dimana pada tahun 2008 angkanya sebesar 96.2 persen terus meningkat sampai tahun 2012 sebesar 96.99 persen. Pada komponen RataRata Lama Sekolah juga mengalami peningkatan yang berarti dimana pada tahun 2008 sebesar 8.5 persen, meningkat pada tahun 2012 sebesar 8.93 persen.

\section{Pengujian Model}

Dalam data panel, terdapat tiga teknik analisis yang digunakan yaitu common effect, fixed effect dan random effect. Untuk mendapatkan model yang tepat dariketiga teknik analisis tersebut, perlu dilakukan pengujianpengujian berikut, yaitu FTest (Uji Chow), Uji Hausman serta Uji Lagrange Multiplier (LM). Hasil estimasidengan ketiga cara tersebut dapat dilihat pada table 4.1. 
Tabel 1. Pengujian Model untuk Pengaruh Dana Otsus terhadap Indeks Pembangunan Manusia

\section{Common Effect}

\begin{tabular}{lrlrr}
\hline \hline \multicolumn{1}{c}{ Variable } & Coefficient & \multicolumn{1}{c}{ Std. Error } & t-Statistic & Prob. \\
\hline \multicolumn{1}{c}{ C } & 7587.023 & 80.83475 & 93.85844 & 0.0000 \\
\multicolumn{1}{c}{ DO } & $-3.86 \mathrm{E}-09$ & $7.58 \mathrm{E}-10$ & -5.092435 & 0.0000 \\
\hline \hline R-squared & 0.225635 & Mean dependent var & 7193.319 \\
Adjusted R-squared & 0.216934 & S.D. dependent var & 254.4596 \\
S.E. of regression & 225.1738 & Akaike info criterion & 13.69336 \\
Sum squared resid & 4512588. & Schwarz criterion & 13.74854 \\
Log likelihood & -621.0477 & Hannan-Quinn criter. & 13.71562 \\
F-statistic & 25.93289 & Durbin-Watson stat & 0.139307 \\
Prob(F-statistic) & 0.000002 & & \\
\hline \hline
\end{tabular}

\section{Fixed Effect}

\begin{tabular}{|c|c|c|c|c|}
\hline Variable & Coefficient & Std. Error & t-Statistic & Prob. \\
\hline C & 6832.974 & 34.85663 & 196.0309 & 0.0000 \\
\hline DO & 3.53E-09 & $3.40 \mathrm{E}-10$ & 10.39582 & 0.0000 \\
\hline \multicolumn{5}{|c|}{ Effects Specification } \\
\hline \multicolumn{5}{|c|}{ Cross-section fixed (dummy variables) } \\
\hline R-squared & 0.985875 & \multicolumn{2}{|l|}{ Mean dependent var } & 7193.319 \\
\hline Adjusted R-squared & 0.981026 & \multicolumn{2}{|l|}{ S.D. dependent var } & 254.4596 \\
\hline S.E. of regression & 35.05073 & \multicolumn{2}{|l|}{ Akaike info criterion } & 10.17278 \\
\hline Sum squared resid & 82313.10 & \multicolumn{2}{|l|}{ Schwarz criterion } & 10.83498 \\
\hline Log likelihood & -438.8613 & \multicolumn{2}{|l|}{ Hannan-Quinn criter. } & 10.43993 \\
\hline F-statistic & 203.3199 & \multicolumn{2}{|l|}{ Durbin-Watson stat } & 1.577750 \\
\hline Prob(F-statistic) & 0.000000 & & & \\
\hline
\end{tabular}

QE Journal |Vol.03 - No.04 December 2014 - 254 
3. Random Effect

\begin{tabular}{|c|c|c|c|c|}
\hline Variable & Coefficient & Std. Error & t-Statistic & Prob. \\
\hline $\begin{array}{c}C \\
D O\end{array}$ & $\begin{array}{l}6872.632 \\
3.14 \mathrm{E}-09\end{array}$ & $\begin{array}{r}55.83937 \\
3.32 E-10\end{array}$ & $\begin{array}{l}123.0786 \\
9.457522\end{array}$ & $\begin{array}{l}0.0000 \\
0.0000\end{array}$ \\
\hline \multicolumn{5}{|c|}{ Effects Specification } \\
\hline & & & S.D. & Rho \\
\hline Cross-section random & & & 212.3277 & 0.9735 \\
\hline Idiosyncratic random & & & 35.05073 & 0.0265 \\
\hline \multicolumn{5}{|c|}{ Weighted Statistics } \\
\hline R-squared & 0.434174 & \multirow{5}{*}{\multicolumn{2}{|c|}{$\begin{array}{l}\text { Mean dependent var } \\
\text { S.D. dependent var } \\
\text { Sum squared resid } \\
\text { Durbin-Watson stat }\end{array}$}} & 594.6822 \\
\hline Adjusted R-squared & 0.427816 & & & 55.11590 \\
\hline S.E. of regression & 40.11338 & & & 143208.4 \\
\hline F-statistic & 68.29208 & & & 0.820383 \\
\hline Prob(F-statistic) & 0.000000 & & & \\
\hline \multicolumn{5}{|c|}{ Unweighted Statistics } \\
\hline R-squared & -0.515891 & Mean dependent var & & 7193.319 \\
\hline Sum squared resid & 8833808. & Durbin-Watson stat & & 0.013300 \\
\hline
\end{tabular}

Sumber :Hasil Pengolahan Data, Eviews 7 (2014)

Tabel 1 menunjukkan bahwa hasil estimasi dari ketiga model tersebut memiliki nilai yang berbeda-beda, nilai yang signifikan adalah Common Effect, Fixed Effect dan Random Effect yang memiliki probabilitas (p-value) sebesar 0,0000 karena dengan $\alpha=5$ persen probabiliti yang didapat lebih kecil dari 0,05, Fixed Effect p-valuenya juga lebih kecil dari $\alpha=5$ persen $(0,0000>0,05)$ dan Random Effect $(0,0000>0,05)$ artinya ketiga model tersebut bisa digunakan dalam analisis data panel pada pengaruh Dana Otonomi Khusus terhadap Indeks Pertumbuhan Manusia. Namun masih diperlukan uji untuk memilih model yang lebih tepat, maka dipakai Uji Chow antara Pool atau Common Effect dengan Fixed Effect dan Uji Hausman untuk memilih antara Random Effect dengan Fixed effect.

\section{Hasil Uji F (Uji Chow)}

Uji Chow test atau Uji F digunakan untuk membandingkan antara Common Effect atau Pool Effect Model dengan Fixed Effect Model sebagai model yang 
paling cocok untuk analisis data panel. Adapun hipotesis dalam pengujian F test adalah sebagai berikut:

\section{$\mathrm{H}_{0}$ :Common Effect atau Pool Effect Model}

$\mathrm{H}_{1}$ :Fixed Effect Model

Kriteria jika $F_{h i t}>F_{\text {tabel }}$ maka $\mathrm{H}_{0}$ ditolak dan terima $\mathrm{H}_{1}$.

Tabel 2. Hasil F test (Uji Chow) untuk Pengaruh Dana Otsus terhadap Indek Pembangunan Manusia

Redundant Fixed Effects Tests

Test cross-section fixed effects

\begin{tabular}{lrrr}
\hline \hline Effects Test & Statistic & d.f. & Prob. \\
\hline \hline Cross-section F & 163.913178 & $(22,67)$ & 0.0000 \\
Cross-section Chi-square & 364.372728 & 22 & 0.0000 \\
\hline \hline F-statistic = 25.93289 & F-tabel & 2.78 & \\
\hline \hline
\end{tabular}

Cross-section fixed effects test equation:

Dependent Variable: IPM

Method: Panel Least Squares

Sample: 20092012

Periods included: 4

Cross-sections included: 23

Total panel (unbalanced) observations: 91

\begin{tabular}{lrlrr}
\hline \hline \multicolumn{1}{c}{ Variable } & Coefficient & Std. Error & t-Statistic & Prob. \\
\hline \hline \multicolumn{1}{c}{ DO } & 7587.023 & 80.83475 & 93.85844 & 0.0000 \\
\multicolumn{1}{c}{ DO } & $-3.86 \mathrm{E}-09$ & $7.58 \mathrm{E}-10$ & -5.092435 & 0.0000 \\
\hline \hline R-squared & 0.225635 & Mean dependent var & 7193.319 \\
Adjusted R-squared & 0.216934 & S.D. dependent var & 254.4596 \\
S.E. of regression & 225.1738 & Akaike info criterion & 13.69336 \\
Sum squared resid & 4512588. & Schwarz criterion & 13.74854 \\
Log likelihood & -621.0477 & Hannan-Quinn criter. & 13.71562 \\
F-statistic & 25.93289 & Durbin-Watson stat & 0.139307 \\
Prob(F-statistic) & 0.000002 & & \\
\hline \hline
\end{tabular}

Sumber :Hasil Pengolahan Data, Eviews 7 (2014)

QE Journal | Vol.03 - No.04 December 2014 - 256 
Berdasarkan hasil estimasi tabel 2 dapat dilihat bahwa nilai $\mathrm{F}$ test dan Chisquare pada Indeks Pembangunan Manusia sebesar 163,913178 dan 364,372728 dengan F-statistik lebih besar dari F-tabel $(25,93289$ > 2,78), sehingga $\mathrm{H}_{0}$ ditolak dan $\mathrm{H}_{1}$ diterima. Kesimpulannya adalah pendekatan dengan Fixed Effect Model sebagai teknik analisis yang lebih sesuai dari pada Common Effect Model. Berdasarkan hasil Uji Chow dapat disimpulkan bahwa Fixed Effect Model merupakan teknik analisis yang paling sesuai untuk digunakan dalam analisis pengaruh Dana Otonomi Khusus terhadap Indeks Pembangunan Manusia.

\section{HasilUjiHausman}

UjiHausmandigunakanuntukmembandingkanantaraRandom Effect Model dengan Fixed Effect Model sebagai model yang paling cocok untuk analisis data panel. Adapun hipotesis dalam pengujian Hausman adalah sebagai berikut:

\section{$\mathrm{H}_{0}:$ Random Effect Model}

\section{$\mathrm{H}_{\mathrm{A}}$ :Fixed Effect Model}

Kriteria jika $\mathrm{X}^{2}$ hit $>\mathrm{X}^{2}(\mathrm{p}, \alpha)$, dimana $\mathrm{P}=$ jumlah koefisien slope atau $\mathrm{P}$-value lebih kecil daripada alpha $(\mathrm{P}$-value $<\alpha)$.

Tabel 3. Hasil Uji Hausman untuk Pengaruh Dana Otsus Terhadap Indeks Pembangunan Manusia

Correlated Random Effects - Hausman Test

Equation: Hijrah

Test cross-section random effects

\begin{tabular}{lrrr}
\hline \hline Test Summary & Chi-Sq. Statistic & Chi-Sq. d.f. & Prob. \\
\hline \hline Cross-section random & 28.770431 & 1 & 0.0000 \\
\hline \hline
\end{tabular}

Cross-section random effects test comparisons:

\begin{tabular}{ccccc}
\hline \hline Variable & Fixed & Random & $\operatorname{Var}($ Diff. & Prob. \\
\hline \hline DO & 0.000000 & 0.000000 & 0.000000 & 0.0000 \\
\hline \hline
\end{tabular}


Cross-section random effects test equation:

Dependent Variable: IPM

Method: Panel Least Squares

Sample: 20092012

Periods included: 4

Cross-sections included: 23

Total panel (unbalanced) observations: 91

\begin{tabular}{|c|c|c|c|c|}
\hline Variable & Coefficient & Std. Error & t-Statistic & Prob. \\
\hline C & 6832.974 & 34.85663 & 196.0309 & 0.0000 \\
\hline DO & 3.53E-09 & $3.40 \mathrm{E}-10$ & 10.39582 & 0.0000 \\
\hline \multicolumn{5}{|c|}{ Effects Specification } \\
\hline \multicolumn{5}{|c|}{ Cross-section fixed (dummy variables) } \\
\hline R-squared & 0.985875 & \multicolumn{2}{|l|}{ Mean dependent var } & 7193.319 \\
\hline Adjusted R-squared & 0.981026 & \multicolumn{2}{|l|}{ S.D. dependent var } & 254.4596 \\
\hline S.E. of regression & 35.05073 & \multicolumn{2}{|l|}{ Akaike info criterion } & 10.17278 \\
\hline Sum squared resid & 82313.10 & \multicolumn{2}{|l|}{ Schwarz criterion } & 10.83498 \\
\hline Log likelihood & -438.8613 & \multicolumn{2}{|l|}{ Hannan-Quinn criter. } & 10.43993 \\
\hline F-statistic & 203.3199 & \multirow{2}{*}{\multicolumn{2}{|c|}{ Durbin-Watson stat }} & 1.577750 \\
\hline Prob(F-statistic) & 0.000000 & & & \\
\hline
\end{tabular}

Sumber :HasilPengolahan Data, Eviews 7 (2014)

Berdasarkan tabel hasil analisis dapat disimpulkan bahwa nilai Chi-square pada Indeks Pembangunan Manusia sebesar 28,770431 dengan probabilitas (p-value) sebesar 0,0000 artinya signifikan pada $\alpha=5$ persen karena p-value lebih kecil dari 0,05 $(0,0000<0,05)$, sehingga $\mathrm{H}_{0}$ ditolak dan $\mathrm{H}_{1}$ diterima. Kesimpulannya adalah dengan tingkat keyakinan 95 persen, pendekatan dengan Fixed Effect Model sebagai teknik analisis yang lebih sesuai dari pada Random Effect Model. Hasil Uji Hausman dapat disimpulkan bahwa Fixed Effect Model merupakan teknik analisis yang paling sesuai untuk digunakan dalam analisis pengaruh Dana Otonomi Khusus terhadap Indeks Pembangunan Manusia.

Kesimpulan dari uraian yang dijelaskan sebelumnya adalah dalam penelitian ini metode yang paling baik atau yang paling sesuai adalah Fixed Effect Model, karena dari hasil Uji F (Uji Chow) dan Uji Hausman menunjukkan untuk analisis Dana Otonomi Khusus terhadap Indeks Pembangunan Manusia model yang paling tepat dan signifikan bagi hasil

QE Journal | Vol.03 - No.04 December 2014 - 258 
estimasi analisis regresi adalah model Fixed Effect. Dengan demikian, LM test, yaitu pengujian untuk memilih antara Common Effect Model atau Pool Effect Model dengan Random Effect Model tidak diperlukan lagi.

\section{Hasil Analisis Regresi}

Analisis yang akan dilakukan adalah pengaruh Dana Otonomi Khusus terhadap Indeks Pembangunan Manusia pada 23 kabupaten/kota di Provinsi Aceh. Adapun hasil analisisnya dapat dilihat pada Tabel 4.

Tabel 4. Hasil Analisis Regresi untuk Pengaruh Dana Otsus terhadap Indeks Pembangunan Manusia dengan Metode Fixed Effect Model

Fixed Effect Model

\begin{tabular}{|c|c|c|c|c|}
\hline Variable & Coefficient & Std. Error & t-Statistic & Prob. \\
\hline $\begin{array}{c}\mathrm{C} \\
\mathrm{DO}\end{array}$ & $\begin{array}{l}6832.974 \\
3.53 E-09\end{array}$ & $\begin{array}{l}34.85663 \\
3.40 E-10\end{array}$ & $\begin{array}{l}196.0309 \\
10.39582\end{array}$ & $\begin{array}{l}0.0000 \\
0.0000\end{array}$ \\
\hline \multicolumn{5}{|c|}{ Effects Specification } \\
\hline \multicolumn{5}{|c|}{ Cross-section fixed (dummy variables) } \\
\hline $\begin{array}{l}\text { R-squared } \\
\text { Adjusted R-squared } \\
\text { S.E. of regression } \\
\text { Sum squared resid } \\
\text { Log likelihood } \\
\text { F-statistic } \\
\text { Prob(F-statistic) }\end{array}$ & $\begin{array}{r}0.985875 \\
0.981026 \\
35.05073 \\
82313.10 \\
-438.8613 \\
203.3199 \\
0.000000\end{array}$ & $\begin{array}{l}\text { Mean dependent var } \\
\text { S.D. dependent var } \\
\text { Akaike info criterion } \\
\text { Schwarz criterion } \\
\text { Hannan-Quinn criter. } \\
\text { Durbin-Watson stat }\end{array}$ & & $\begin{array}{l}7193.319 \\
254.4596 \\
10.17278 \\
10.83498 \\
10.43993 \\
1.577750\end{array}$ \\
\hline
\end{tabular}

Sumber :Hasil Pengolahan Data, Eviews 7 (2014)

Nilai konstanta sebesar 6832.974 menjelaskan apabila diasumsikan realisasi Dana Otsus adalah tetap (tidak mengalami perubahan), maka tingkat IPM pada 23 kabupaten/kota di Provinsi Aceh akan mengalami penurunan sejumlah 68,33 persen. Koefisien untuk Dana Otsus sebesar 0.00000000353 menjelaskan bahwa Dana Otsus berpengaruh positif terhadap Indeks Pembangunan Manusia, artinya setiap meningkat Dana Otsus sebesar satu persen, maka dapat meningkatkan IPM sebesar 0.000000353 persen dengan asumsi cateris paribus. Apabila dilihat dari nilai Thitung variabel sebesar 196,0309 dengan probabilitas sebesar 0,0000, artinya probabilitas ( $\mathrm{p}$-value) lebih kecil dari $\alpha=5$ persen $(0,0000<0,05)$ sehingga dengan tingkat

QE Journal | Vol.03 - No.04 December 2014 - 259 
keyakinan 95 persen dapat disimpulkan kita menolak hipotesis nol $\left(\mathrm{H}_{0}\right)$. Kesimpulannya adalah realisasi Dana Otsus berpengaruh positif dan signifikan terhadap IPM. Nilai Adj.R ${ }^{2}$ adalah 0,9810 yang artinya 98,10 persen IPM dipengaruhi oleh realisasi Dana Otsus dan 1,90 persen dipengaruhi oleh variabel lain.

\section{SIMPULAN DAN SARAN}

\section{Simpulan}

Indeks Pembangunan Manusia di pengaruhi oleh alokasi dana Otsus pada periode 2009-2012. Dana Otsus mempunyai pengaruh yang positif dan signifikan terhadap Indeks Pembangunan Manusia, dimana peningkatan dana Otsus beriringan dengan peningkatan Indeks Pembangunan Manusia. Sehingga dapat disimpulkan bahwa peningkatan dana Otsus berpengaruh positif terhadap Indeks Pembangunan Manusia.

\section{Saran}

Dari analisa tersebut maka, pemerintah sebaiknya lebih membuat terobosan kebijakan yang efektif dan efisien baik itu berupa perencanaan maupun implementasinya serta transparansi dalam hal pengelolaan dana Otsus. Sehingga sumber-sumber penerimaan daerah khususnya penerimaan dari dana Otsus dapat tersalurkan ke berbagai sektor unggulan tidak hanya terfokus pada sektor infrastruktur saja tetapi harus ada kuota yang cukup untuk alokasi pada Pembangunan Manusia yang paling utama terfokus kepada sektor pendidikan, dimana pemicu peningkatan tingkat kesejahteraan masyarakat akan ditopang oleh tingkat pendidikan yang baik. Dengan adanya tingkat pendidikan yang baik maka instrumen dari Indeks Pembangunan manusia dengan sendiri nya akan ikut meningkat. Selanjutnya kepada peneliti selanjutnya, untuk bisa menambah variabel lain yang lebih luas dan lebih mendalam karena alokasi Dana Otsus tidak hanya di fokuskan kepada sektor Indeks Pembangunan Manusia saja tetapi ada sektor-sektor lain yang lebih strategis diantaranya mensertakan sektor yang lebih dominan diantaranya di bidang Infrastruktur, pendidikan, pengentasan kemiskinan, sosial budaya, kesehatan dan sektor-sektor lainnya. Sehingga dari penelitian tersebut menghasilkan suatu kesimpulan yang lebih baik. 


\section{DAFTAR PUSTAKA}

Badan Pusat Statistik Aceh (2010). Laporan Pembangunan Manusia. Banda Aceh.

Bappeda Aceh (2013). Keuangan dan Harga-harga. Banda Aceh

Decentralization Support Facility (2011). Kajian Pengelolaan dan Pemanfataan Dana Otonomi Khusus Aceh. Banda Aceh.

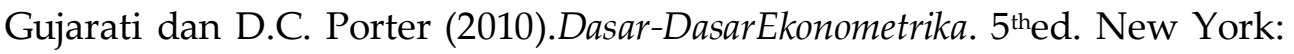
McGraw-Hill Companies, Inc.

Jaya, W.K (2010). Kebijakan Desentralisasi di Indonesia di Indonesia dalam Perspektif Teori Ekonomi Kelembagaan. Yogyakarta.

Pecapp (2013).AnalisisBelanjaPublik Aceh. Banda Aceh.

Republik Indonesia. Pasal 18 B Ayat (1) UUD NRI 1945, Sekretariat Negara, Jakarta

Republik Indonesia. Pasal 18 B Ayat (1) UUD NRI 1945, Sekretariat Negara, Jakarta.

Republik Indonesia. 1998. TAP MPR Nomor XV/MPR/1998 tentang Penyelenggaraan Otonomi Daerah. Sekretariat Negara, Jakarta.

United Nations Development Programme (1996), Human Development Report 1996, Economic and Human Development, Published for United Nations Development Programme. New York: Oxford University Press. 


\section{QUANTITATIVE ECONOMICS JOURNAL WRITING GUIDANCE}

The journal is published by the Department of Economics, Post Graduate Program State University of Medan in online and print editions. This journal contained the articles of economics, both the results of research and engineering ideas that are quantitative. The views expressed in this publication are those of the author(s) and do not necessarily reflect those of Department of Economics, Post Graduate Program, State University of Medan.

The journal is published four times a year, ie in March (first volume), June (second volume), September (third volume), and December (fourth volume). All contents of this journal can be viewed and downloaded free of charge at the website address: http://qe-journal.unimed.ac.id . We invite all parties to write in this journal. Paper submitted in soft copy (file) to: imaipita@gmail.com cc: gejournal@unimed.in. See the writing guide on the back of this journal.

\section{GENERAL GUIDELINES}

1. Scripts must be original work of the authors (individuals, groups or institutions) that do not violate copyright.

2. Manuscripts submitted have not been published or not published and is being sent to other publishers at the same time.

3. Copyrighted, published manuscripts and all its contents remain the responsibility of the author.

4. Highly recommended to submit the manuscript in the form of soft copy (file) to the email address: imaipita@gmail.com cc: gejournal@unimed.in

5. Manuscript restricted ranges 15-17 A4 pages, single spaced, font Palatino Linotype with font size 11.

6. Mathematical equations and symbols, please written using Microsoft Equation.

7. Scripts can be written in the Indonesian language atu in English.

8. Each manuscript must be accompanied by abstract of about $150-250$ words. Abstract written in English, and keywords.

9. Title tables and figures are written parallel to the image / table, sentence case, with 6 pt spacing of tables or pictures. Title of the table is placed on top of the table, while the image title is placed below the image. Writing the source tables or images are placed under the tables and figures with $10 \mathrm{pt}$ font).

example: 


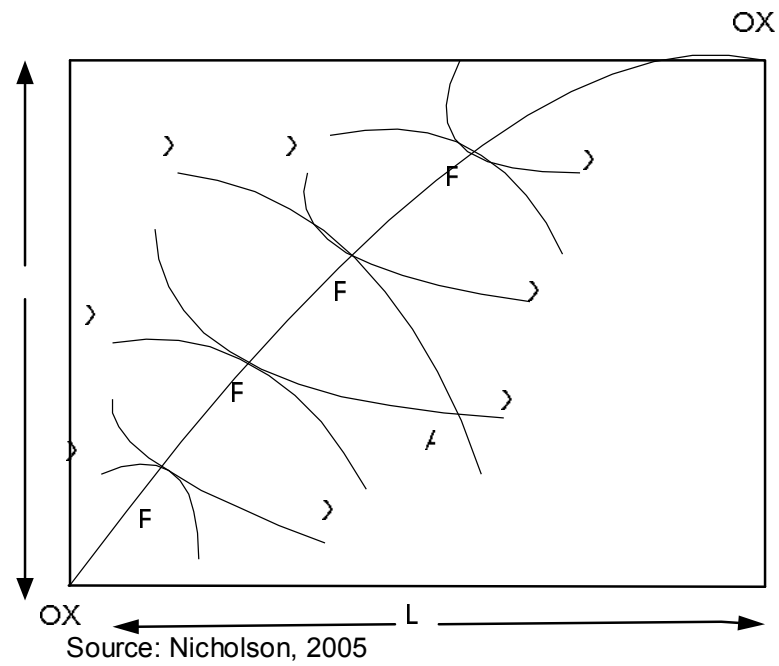

Figure 2.11. Equilibrium In Production Sector

Table 4.2 The Impact of Policy Scenario

\begin{tabular}{lrrr}
\hline \multirow{2}{*}{ Household } & \multicolumn{3}{c}{ Changes } \\
\cline { 2 - 4 } & \multicolumn{1}{c}{ Simulation 1_a } & simulation 1_b & simulation 1_c \\
\hline HUNPOOR & -0.3892 & -1.2256 & -2.4192 \\
HUPOOR & -0.4024 & -1.2694 & -2.4618 \\
HRNPOOR & -0.3640 & -1.1587 & -2.3256 \\
HRPOOR & -0.3406 & -1.0840 & -2.1471 \\
\hline
\end{tabular}

Source: Maipita and Jantan (2010)

10. Citation ofreferencesfollow the following rules:

a. Singleauthor(Maipita, 2010)orMaipita(2010).

b. Twoauthors (Maipita andMales, 2011)orMaipitaandMales(2011)

c. More thantwoauthors: (Maipita etal, 2011)orMaipitaetal(2011).

d. Two sourceswithwriting the samequotebuta differentyear(Chiang, 1984;Dowling. 1995).

e. Two sourceswithwriting the samequotebuta differentyear(Friedman. 1972;1978).

f. Twoquotesfroma writerbutthe sameyear(Maipita. 2010a, 2010b).

g. Excerptsfrom theagency, preferably inacronyms(BPS,2001).

11. Manuscriptmust be accompaniedbythe dataauthors, institutionaladdressesand e-mail that can be contacted. It is advisable towrite thebiographical datain the form ofCV(curriculumvitae) short.

\section{SPECIAL GUIDELINES}

The structure of the writing in this journal are as follows:

QE Journal | Vol.03 - No.04 December 2014 - vi 


\author{
THE TITLE OF ARTICLE \\ The first author's name, \\ Institution, address, \\ Tel., Email: \\ The second author's name \\ The author's name etc. \\ example: \\ THE MODEL OF POVERTY EVALUATION PROGRAM \\ Mohd. Dan Jantan \\ Department of Economics, Universiti Utara Malaysia, Kedah, Malaysia \\ Te.: +604-928 3543, E-Mail: djantan@uum.edu.my
}

\title{
Abstract
}

Abstract written in English as much as 150-250 words. Abstract written in one paragraph, containing briefly the purpose, research methods and results.

Keywords: (maximum of 5 keywords)

JEL Classification:

\section{INTRODUCTION}

This section contains a brief research background, objectives, and support the theory. If it is not very important, this portion does not need to use a subtitle or subsection.

\section{RESEARCH METHODS}

Describe the research method used is concise and clear on this portion. This portion may contain subsections or subtitled but do not need to use the numbering.

\section{RESULTS AND DISCUSSION}

This section is the part most of all parts of the article, contains a summary of data, data analysis, research and discussion. This section should only contain sub-section without numbering.

\section{CONCLUSION AND SUGGESTIONS}

Contains the results or conclusions of research findings in brief and concise. While the advice is a recommendation based on research results and / or further research suggestions.

\section{REFERENCES}

Bibliography contains only a reference that actually referenced in the article. Not justified to include references that are not referenced in the article to this section.

Some specific provisions of the writing of the bibliography are as follows:

- References are sorted alphabetically (ascending).

- Posting the author's name follows the form: last name, first name.

- Systematics of writing for a book: author's name. year of publication. Book title. Publisher, city. example:

QE Journal | Vol.03 - No.04 December 2014 - vii 
Maipita, Indra. 2010. Quantitative Methods of Economic Research. Madinatera, Medan.

- Systematics of writing for journals: author's name. year of publication. Writing title. name of the journal. Volume, number (page). example:

Maipita, Indra., Dan Jantan, and Noor Azam. 2010. The Impact of Fiscal Policy Toward Economic Performance and Poverty Rate in Indonesia. Bulletin of Monetary Economics and Banking Vol 12, Number 4, April 2010 (391-424).

- Systematics of writing for the thesis/dissertation: The name of the author. years. The title. Thesis / Dissertation. The University. example:

Maipita, Indra. 2011. The Impact Analysis of Fiscal Adjustment on Income Distribution and Poverty in Indonesia: Computable General Equilibrium Approach. Dissertation. Universiti Utara Malaysia.

- Systematics of writing for an article from the internet: the name of the author. years. Title of the paper. Accessed from the website address at the date of month year. example:

Friedman, J. (2002). How responsive is Poverty to Growth?: A Regional Analysis of Poverty, Inequality, and Growth in Indonesia, 1984-1999. Retrieved from www.ciaonet.org/wps/rijo2/ on January 19, 2009.

- Systematics of writing for an article in the newspaper/magazine: the name of the author. date, month and year of publication. Title of the paper. The name of the newspaper. Publisher, city. 


\section{QUANTITATIVE ECONOMICS JOURNAL KETENTUAN PENULISAN ARTIKEL}

Jurnal ini diterbitkan oleh Program Studi Ilmu Ekonomi Program Pascasarjana Universitas Negeri Medan dalam edisi online dan cetak. Berisi artikel bidang IImu Ekonomi baik hasil penelitian maupun rekayasa ide yang bersifat kuantitatif. Isi dan hasil penelitian dalam tulisan di jurnal ini sepenuhnya tanggung jawab para penulis.

Jurnal ini diterbitkan empat kali dalam setahun, yaitu pada bulan Maret (volume pertama), Juni (volume kedua), September (volume ketiga), dan Desember (volume keempat). Artikel dapat ditulis dalam bahasa Indonesia maupun dalam bahasa Inggris. Semua isi jurnal ini dapat dilihat dan diunduh secara cuma-cuma pada alamat website: http://qe-journal.unimed.ac.id . Kami mengundang semua pihak untuk menulis pada jurnal ini. Paper dikirimkan dalam bentuk soft copy (file) ke: imaipita@gmail.com cc: gejournal@unimed.in.

\section{KETENTUAN UMUM}

1. Naskah harus merupakan karya asli penulis (perorangan, kelompok atau institusi) yang tidak melanggar hak cipta.

2. Naskah belum pernah dimuat atau diterbitkan dan tidak sedang dikirimkan ke penerbit lain pada waktu yang bersamaan.

3. Hak cipta naskah yang diterbitkan besrta segala tanggungjawab isinya tetap pada penulis.

4. Sangat dianjurkan untuk mengirimkan naskah dalam bentuk soft copy (file) ke alamat email: imaipita@gmail.com cc: gejournal@unimed.in

5. Naskah dibatasi berkisar 15-17 halaman berukuran A4, spasi satu, huruf Palatino Linotype dengan ukuran huruf 11.

6. Persamaan matematis dan simbol, harap ditulis menggunakan Microsoft Equation.

7. Naskah dapat ditulis dalam bahasa Indonesia atu dalam Bahasa Inggris.

8. Setiap naskah harus disertai Abstrak sekitar 150-250 kata. Abstrak ditulis dalam bahasa Inggris, beserta kata kuncinya.

9. Judul tabel dan gambar ditulis sejajar gambar/tabel,dengan jarak 6 pt dari tabel atau gambarnya. Judul tabel diletakkan di atas tabel, sedangkan judul gambar diletakkan di bawah gambar. Penulisan sumber tabel atau gambar diletakkan di bawah tabel atau gambar dengan huruf $10 \mathrm{pt})$.

Contoh: 
o)

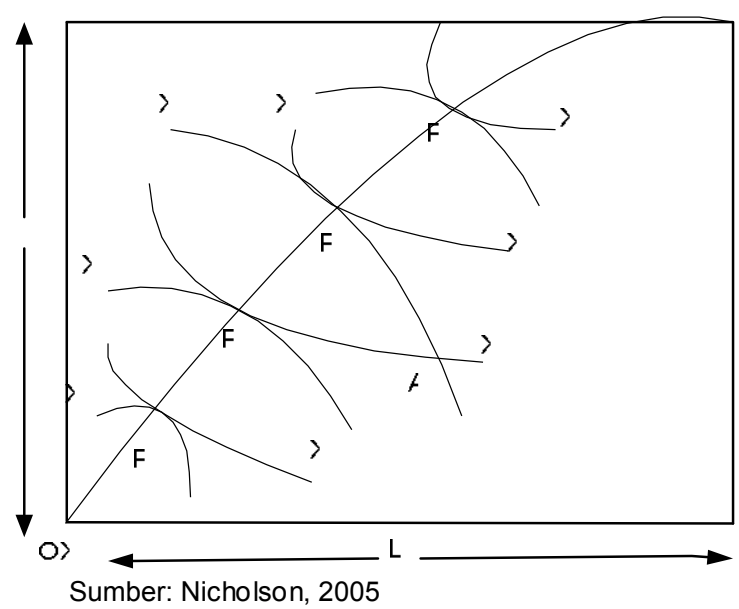

Gambar 2.11. Keseimbangan di Sektor Produksi

Tabel 4.2. Dampak Skenario Kebijakan

\begin{tabular}{lrrr}
\hline \multirow{2}{*}{ Rumahtangga } & \multicolumn{3}{c}{ Perubahan } \\
\cline { 2 - 4 } & \multicolumn{1}{c}{ Simulasi 1_a } & simulasi 1_b & simulasi 1_c \\
\hline HUNPOOR & -0.3892 & -1.2256 & -2.4192 \\
HUPOOR & -0.4024 & -1.2694 & -2.4618 \\
HRNPOOR & -0.3640 & -1.1587 & -2.3256 \\
HRPOOR & -0.3406 & -1.0840 & -2.1471 \\
\hline
\end{tabular}

Sumber: Maipita dan Jantan (2010)

10. Pengutipan bahan rujukan mengikuti aturan berikut:

a. Penulisan tunggal (Maipita, 2010) atau Maipita (2010)

b. Dua penulis (Maipita dan Jantan, 2011) atau Maipita dan Jantan (2011)

c. Penulis lebih dari dua orang : (Maipita et al, 2011) atau Maipita et al (2011)

d. Dua sumber kutipan dengan penulisan yang sama tetapi tahunnya berbeda (Chiang, 1984; Dowling. 1995)

e. Dua sumber kutipan dengan penulisan yang sama tetapi tahunnya berbeda (Friedman. 1972; 1978)

f. Dua kutipan dari seorang penulis tapi tahunnya sama (Maipita. 2010a, 2010b)

g. Kutipan dari instansi, sebaiknya dalam singkatan lembaga (BPS, 2001)

11. Naskah harus disertai dengan biodata penulis, alamat institusi dan e-mail yang dapat dihubungi. Disarankan untuk menulis biodata dalam bentuk CV (curriculum vitae) pendek.

\section{KETENTUAN KHUSUS}

Struktur penulisan dalam jurnal ini adalah sebagai berikut:

QE Journal |Vol.03 - No.04 December 2014 - x 
JUDUL ARTIKEL

Nama penulis pertama,

Institusi, alamat,

Telp., email:

Nama penulis kedua

Nama penulis seterusnya

Contoh:

MODEL ESTIMASI NILAI TAMBAH BRUTO SEKTOR PERTANIAN TERHADAP AKUMULASI INVESTASI

Mohd. Dan Jantan

Department of Economics, Universiti Utara Malaysia, Kedah, Malaysia

Te.: +604-928 3543, E-Mail: diantan@uum.edu.my

\section{Abstract}

Abstrak ditulis dalam bahasa inggris dengan banyak kata 150-250 kata. Abstrak ditulis dalam satu paragraf, memuat secara singkat tujuan, metode penelitian dan hasil.

Keywords: (maksimum 5 kata kunci)

JEL Classification:

\section{PENDAHULUAN}

Bahagian ini memuat latar belakang penelitian secara singkat, tujuan, serta dukungan teori. Jika tidak sangat penting, bahagian ini tidak perlu menggunakan subjudul atau subbahagian.

\section{METODE PENELITIAN}

Uraikan metode penelitian yang digunakan secara ringkas dan jelas pada bahagian ini. Bahagian ini boleh memuat subbab atau subjudul namun tidak perlu menggunakan penomoran.

\section{HASIL DAN PEMBAHASAN}

Bahagian ini merupakan bahagian terbanyak dari semua bahagian artikel, memuat data secara ringkas, analisis data, hasil penelitian dan pembahasan. Bahagian ini boleh saja memuat subbab tanpa penomoran.

\section{SIMPULAN DAN SARAN}

Simpulan berisi hasil atau temuan penelitian secara ringkas dan padat. Sedangkan saran merupakan rekomendasi berdasarkan hasil kajian dan/atau saran penelitian lanjutan.

\section{DAFTAR PUSTAKA}

Daftar pustaka hanya memuat referensi yang benar-benar dirujuk dalam artikel yang ditulis. Tidak dibenarkan mencantumkan referensi yang tidak dirujuk dalam tulisan ke bahagian ini.

Beberapa ketentuan khusus dari penulisan daftar pustaka adalah:

- Daftar pustaka diurutkan berdasarkan abjad (ascending).

QE Journal | Vol.03 - No.04 December 2014 - xi 
- Penulisan nama penulis mengikuti bentuk: nama belakang, nama depan.

- Sistematika penulisan untuk buku: nama penulis. tahun publikasi. Judul Buku.Penerbit, kota. Contoh :

Maipita, Indra. 2010. Metode Penelitian Ekonomi Kuantitatif. Madinatera, Medan.

- Sistematika penulisan untuk jurnal: nama penulis. tahun publikasi. Judul Tulisan. nama jurnal. Volume, nomor (halaman). Contoh:

Maipita, Indra., Dan Jantan, Noor Azam. The Impact of Fiscal policy Toward Economic Performance and Poverty Rate in Indonesia. Bulletin of Monetary Economics and Banking Vol 12, Number 4, April 2010 (391-424).

- Sistematika penulisan untuk skripsi/tesis/disertasi: Nama penulis. tahun. Judul. Skripsi/Tesis/Disertasi. Universitas. Contoh:

Maipita, Indra. 2011. The Analysis of Fiscal Adjustment Impact on Income Distribution and Poverty in Indonesia: Computable General Equilibrium Approach. Dissertation. Universiti Utara Malaysia.

- Sistematika penulisan untuk artikel dari internet: nama penulis. tahun. Judul tulisan. Diakses dari alamat website pada tanggal bulan tahun. Contoh:

Friedman, J. (2002). How responsive is Poverty to Growth?: A Regional Analysis of Poverty, Inequality, and Growth in Indonesia, 1984-1999. Retrieved from www.ciaonet.org/wps/fri02/ on January 19, 2009

Sistematika penulisan untuk artikel dalam koran/majalah: nama penulis. tanggal, bulan dan tahun publikasi. Judul tulisan. Nama koran. Penerbit, kota. 

